\title{
16. Boom to Cusp
}

\section{Prospecting the 'new normal' in China and Africa}

\section{Lauren Johnston}

\section{Introduction}

Multiple domestic structural factors underlie China's lower 'new normal' growth target of 7 per cent: reduced export demand growth, an ageing and higher-cost workforce, environmental priorities and constraints, and diminishing returns to physical capital relative to human capital. With the middle-income trap still to be avoided and China home to some 100 million citizens living below the RMB2,300 per annum national poverty line at the end of 2012 (World Bank 2015), finding ways to ensure growth is sustainable and delivers the livelihoods of a high-income country is now an objective of government.

Economic ties with Africa are one source of growth for China. China-Africa trade reached almost US $\$ 200$ billion in 2013 - up from about US $\$ 10$ billion in 2000 (IMF 2015a). Realised annual foreign direct investment (FDI) in Africa in 2013 surpassed US\$3 billion - up from US\$317 million a decade earlier (NBS 2014). Total Chinese investment stock in Africa exceeded US\$26 billion in 2013 (NBS 2014).

Despite the slowing of China's own growth, China-Africa growth prospects remain buoyant. By 2020, intra-developing country trade is forecast to have increased tenfold over a decade, with China-Africa trade leading the way (Fletcher and Ahmed 2012). China's investment in Africa is also set to expand dramatically. Chinese state media announced in late 2013 a national decision to provide US\$1 trillion in financing to Africa by 2025 (Xinhuanet 2013). These growth trajectories will not only shape China's international integration and Africa's economic development prospects, but also come to shape features of the world economy.

Internal debate in Africa about China's rising economic ties with the continent is intense. At the political level, in 2006 Zambian presidential candidate the late president Michael Sata famously accused the Chinese of being 'infestors' rather than investors. South African President Jacob Zuma has been more circumspect, suggesting in 2012 that 'Africa's commitment to China's development has been demonstrated by supply of raw materials, other products and technology 
transfer', adding that '[t]his pattern of trade is unsustainable in the long term. Africa's past economic experience with Europe dictates a need to be cautious when entering into partnerships with other economies' (Hook 2012).

There are governance issues also. In a 2014 transparency index, China was ranked last of 62 donor agencies (Publish What You Fund 2014). The home regions of African presidents are found to receive three to four times more Chinese aid than other regions, leading to accusations that China plays patronage politics (Dreher 2014). Trade with China is also found to be proportionately greater to African countries with a poor governance record (de Grauwe et al. 2012).

In the Financial Times in March 2013, the Central Bank Governor of Africa's largest economy, Nigeria's Sanusi Lamido, wrote that Africa should:

[R]ecognize that China-like the US, Russia, Britain, Brazil and the rest - is in Africa not for African interests but its own. Romance must be replaced by hard-nosed economic thinking. Engagement must be on terms that allow the Chinese to make money while developing the continent, such as incentives to set up manufacturing on African soil and policies to ensure employment of Africans. (Financial Times 2013)

The stakes are high, for both China and Africa. In 2010, current Chinese President and then vice-president, Xi Jinping, promised Africa that China would 'enlarge the scale of China-Africa trade, and optimize the trade structure' (Pang 2010). This is important-during 2005-12, China accounted for some 30 per cent of sub-Saharan Africa's export growth (Drummond and Liu 2013: 10).

China's 'new normal' growth era is, however, now ending the decade-long China-led commodities price boom (Garnaut 2012), which in turn will affect China-Africa economic ties. The majority of Africa's exports to China are raw commodities, especially oil. Visiting Africa in early 2015, International Monetary Fund (IMF) Managing Director Christine Lagarde warned, '[m]omentum is slowing in many advanced and emerging economies, including in China-one of Africa's main trading partners' (Ochelle 2015).

The effects for Africa's commodity and non-commodity exporters alike could be extensive. Dramatic falls in the iron ore price, for example, are a significant factor in the IMF in April 2015 lowering its annual growth forecasts for Guinea, Liberia and Sierra Leone - from 6 to 1 per cent, from 11 to 6 per cent and from 5.4 per cent to 1 per cent respectively (IMF 2015b). The falling iron ore price has delivered an especially harsh blow to the fiscal positions of the three leastdeveloped countries (LDCs) that are battling the aftermath of the worst-ever Ebola virus outbreak. 
This chapter focuses on the evolution of China-Africa economic ties. It sheds light on the importance of China to Africa, and also of Africa to China. The chapter also draws attention to a series of factors that highlight ways in which China's slowdown may not be all bad news for African economies. The end of the commodities boom could instead give rise to gradual investment and trade expansion outside the resources sector - a case of 'boom to cusp' - that could place the continent in a better position for more broadly based growth.

The second section of this chapter presents a short chronological introduction to China-Africa relations, with a focus on economics. The third section presents the stylised facts of contemporary economic ties. The fourth section outlines issues in China-Africa ties, with a focus on trade, especially in oil. The final section draws together the preceding discussion to highlight uncertainty amid potential for the emergence of new sources of growth in China and Africa.

\section{China-Africa: Return of a fleeting 'old normal'}

China's ties with Africa date back to the three fifteenth-century visits of Admiral Zheng He's fleets to the East African coastline (Dreyer 2007). On these visits, Chinese porcelains, silks and crafts were exchanged for African products, fauna and flora (Levathes 2014).

When the People's Republic of China (PRC) was formed in 1949, most of Africa remained under European colonial rule. The first independent African country to establish official diplomatic ties with Beijing was Egypt, in 1956. This marks also the beginning of China's direct aid to Africa (Mao 2011). Other postindependence early movers to recognise Beijing include Guinea and Sudan (in 1959), Ghana (1960), Democratic Republic of the Congo (DR Congo, 1961), Kenya (1963), and Benin and Republic of the Congo (Congo Republic, 1964) (Brautigam 2009: 68).

Premier Zhou Enlai's 1963 visit to 10 mostly newly independent countries was another turning point in Sino-African political economic ties. ${ }^{1}$ The visit delivered the formal launch of China's aid policy for Africa, including a promise of help to construct a railway from Zambia to Tanzania, enabling landlocked Zambia's copper to be exported around Zimbabwe and South Africa. In the years thereafter, African votes were instrumental in Beijing's 1971 win over Taiwan in acquiring China's seat on the UN Security Council (Brautigam 2009).

1 Including United Arab Republic (now Egypt), Algeria, Morocco, Tunisia, Ghana, Mali, Sudan, Ethiopia and Somalia (MFA 2000). 
As Beijing launched its opening and reform policies in the late 1970s, African growth performance was mostly poor to disastrous. Examples include the 1980s economic crises in Guinea and Tanzania. From the mid-1970s to mid-1990s, almost all economies in sub-Saharan Africa (SSA) had zero or negative economic growth per capita (Radelet 2010: 1). Just one African economy made The Growth Report's list of 13 sustained high-growth economies of the later twentieth century: Botswana (World Bank Staff 2008). China's ongoing transformation, in contrast, took place within a neighbourhood of high-performing economies; more than half the economies listed were East Asian. ${ }^{2}$

Macroeconomic conditions in Africa, however, have changed. The majority of economies in SSA have performed better since 1996 (Arbache and Page 2007). The 1994 end of Apartheid in South Africa allowed SSA's then largest economy to reintegrate with the region, while also helping to stabilise regional politics (Carmody 2009). Chinese President Jiang Zemin's visit to Africa in 1996 marks a shift in the driver of Sino-African ties from politics towards economics (Alden 2007: 15).

For China, those changes in Africa and Jiang's official visit came at a ripe time. China's exports of machinery and electronics exceeded those of textiles and clothing in 1995 (Lin and Wang 2014: 4). That rapid industrial growth saw China become a net oil importer in 1991, prompting an international quest for energy and other raw material supplies. Africa was seen as a potential source of undeveloped resources.

In extended outreach to Africa, China also sought support for Chinese policies in international affairs, acceptance of the RMB as an international currency, and the creation of new markets for Chinese goods and services. China offered willingness to invest in Africa's infrastructure and capacity to follow through (Brautigam 2009; Broadman 2007: 11; Pannell 2013). Jiang's visit coincided with a decision of China's State Council to 'combine aid to Africa, mutual cooperation, and trade together' (Brautigam 2009: 80).

For these reasons, Africa is also a focus of China's national-level outbound investment policy. Officially launched in 2000, the 'Going Out' policy aims to gain access to natural resources that are in short supply domestically, to forge international brand names of Chinese origin, and to diversify investments utilising China's trillion-dollar foreign exchange reserves.

Since 2000, growing China-Africa ties are coordinated through the Forum on China and Africa Cooperation (FOCAC), which China instigated in the footsteps of the Europe-Africa Summit and the Tokyo International Conference on

2 The 13 are Botswana, Brazil, China, Hong Kong (China), Indonesia, Japan, Korea, Malaysia, Malta, Oman, Singapore, Taiwan (China) and Thailand. 
African Development (TICAD). Via FOCAC, a triennial head-of-state forum rotate between China and an African host. The sixth such summit will be hosted by South Africa in November 2015. FOCAC is also the umbrella under which more regular ministerial and working groups between Chinese and African governments take place.

Not all African countries are part of FOCAC. Burkina Faso and Swaziland are excluded from FOCAC because China insists that all participants adhere to the One China Policy. Gambia is also excluded as, although in late 2014 it ceased recognising Taipei, it has not agreed to diplomatic ties with Beijing.

FOCAC politically formalised ties between China and Africa in 2000, and since 2009 China has grown to become Africa's largest bilateral trade partner. Since 2009 Africa's trade with China exceeds in value the sum of all intra-African trade (IMF 2015a). The rapid expansion of economic ties helped to transform Africa from the 'hopeless continent' (The Economist 2011) into a new pole of global growth, and home to some of the world's fastest growth rates (The Economist 2011; Wang 2007).

\section{China-Africa economics overview}

Sino-African economic ties run in three interconnected channels: aid, investment and trade. This section provides an overview of those flows, and also outlines their interlaced structure.

China's aid data are presented using a different methodology to that of the Organisation for Economic Cooperation and Development (OECD). This makes it difficult to draw international comparisons (Brautigam 2011a: 203-22; Brandt 2013).

According to the 2014 China White Paper on Foreign Aid, from 2010 to 2012, China provided RMB89.3 billion (US\$13.4 billion) in foreign aid, through grants, interest-free loans (8.1 per cent of total foreign aid) and concessional loans (55.7 per cent of total foreign aid). This three-year sum is equivalent to about one-third of China's entire pre-2009 foreign aid to all countries, according to figures in the first aid white paper of 2011 (Zhou 2014). The amount suggests annual foreign aid of about $\$ 5$ billion, making China the world's tenth-largest provider of foreign aid (Zhou 2014).

The white paper also reveals that about half of China's foreign aid goes to countries in Africa (MOFCOM 2011, 2013). That aid prioritises agricultural development, followed by infrastructure, health, capacity building (education) 
and climate change (MOFCOM 2011, 2013). There were 86 aid-related infrastructure projects under way that seek to better integrate domestic and regional economies (MOFCOM 2011, 2013).

Towards mitigating and adjusting to climate change, China has built several meteorological monitoring stations in African countries, and is active in supporting the development and utilisation of new energy on the continent. Recent projects receiving Chinese state financial support include a 400-megawatt solar power plant in Ghana at a cost of US\$1 billion. Negotiations are in progress around a US\$140 million solar power station in Garissa, Kenya (Tsagas 2013), and a US\$132 million wind farm in Tanzania. Such investments help to address Africa's power gap in a more sustainable way than via old energy models. They also create an international market for Chinese new energy companies. This type of exchange reflects the principle of mutual development that is an explicit founding principle of China's foreign aid program.

And so the line between Chinese aid and investment is a murky one (see Brautigam 2011). The evolution of China's development financing between aid and commercial investment is introduced by Lin and Wang's (2014: 8) summary of China's financing mechanisms available to Africa:

Other Official Flows [OOF] (large but less concessional loans and export credit provided by China EXIM [Export-Import Bank of China]); resource for infrastructure packages; equity investment by ChinaAfrica Development (CAD) fund; infrastructure investment by the China Development Bank (CDB) and other commercial banks (which are OOFlike loans and investments with the intention for development, but nonconcessional, and suitable for long-term infrastructure investment).

As a result of economics and of Chinese policy, China's FDI stock in Africa has risen rapidly in the past decade-from US\$900 million in 2004 to US\$3.37 billion by 2013 (Figure 16.1). Until 2013, the largest single investment made by China in Africa took place in 2008, a year in which China's FDI flow, stock and single largest investment item were comparable in level. FDI stock has since accumulated to vastly exceed any single project or annual flow. The majority of all such Chinese FDI into Africa is loan financed (MOFCOM 2013). It is noted that since government statistics have been found to underestimate the size of outward FDI (Shen 2015), the actual flow and stock levels are probably significantly higher than these official statistics. 


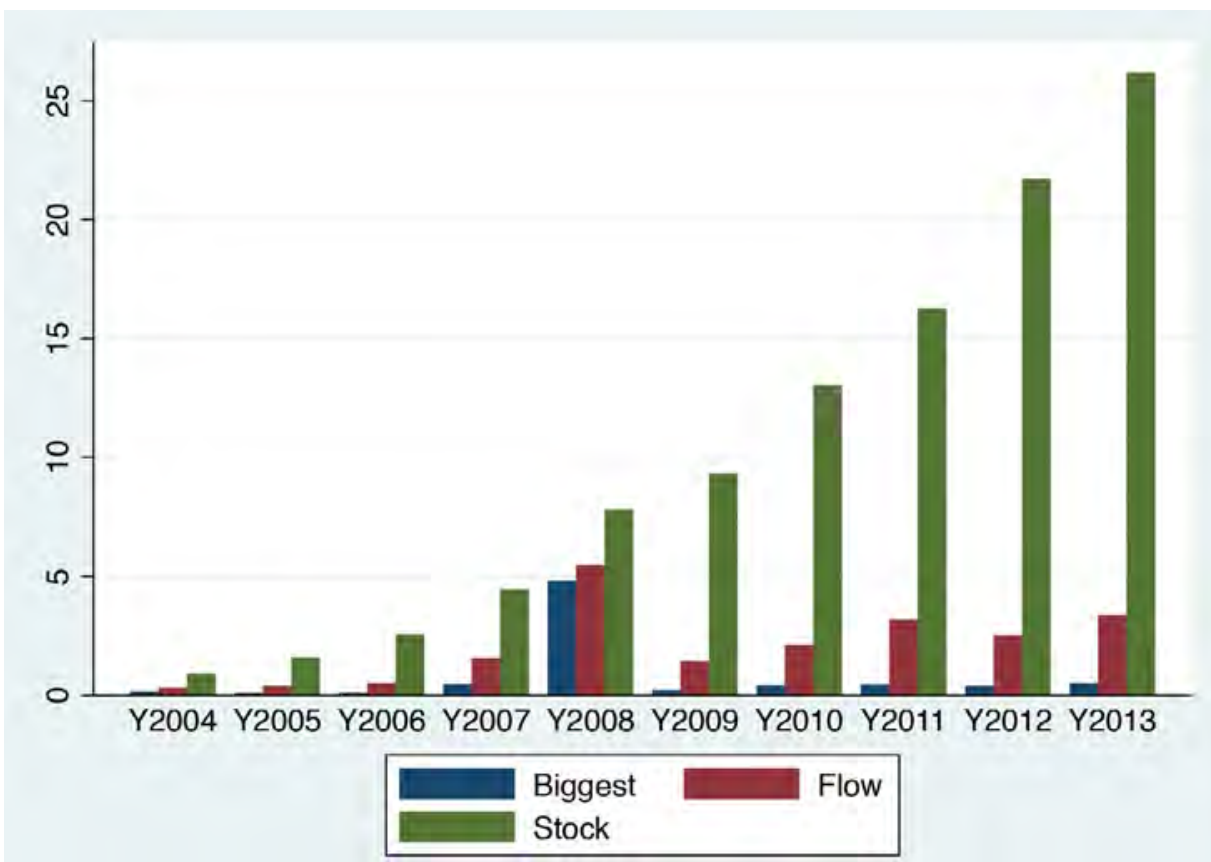

Figure 16.1 Mainland Chinese FDI stock in Africa (US\$ billion)

Sources: NBS $(2013,2014)$.

Table 16.1 Bilateral Chinese FDI into Africa, 2013 (US\$ million)

\begin{tabular}{|l|r|r|}
\hline Country & Flow & Stock \\
\hline Algeria & 191.3 & $1,497.2$ \\
\hline Angola & 224.5 & $1,634.7$ \\
\hline Benin & 8.4 & 49.9 \\
\hline Botswana & 10.2 & 230.9 \\
\hline Burkina Faso & 4.3 & 4.3 \\
\hline Burundi & 1.1 & 9.8 \\
\hline Cameroon & 57.2 & 148.4 \\
\hline Cape Verde & 0.1 & 15.2 \\
\hline Central African Republic & 1.3 & 60.4 \\
\hline Chad & 121.0 & 321.3 \\
\hline Comoros & - & 4.5 \\
\hline Congo Republic & 110.0 & 695.4 \\
\hline Congo, DR & 121.3 & $1,091.8$ \\
\hline Côte d'lvoire & -4.8 & 35.0 \\
\hline Djibouti & 2.0 & 30.6 \\
\hline Egypt & 23.2 & 511.1 \\
\hline
\end{tabular}


China's Domestic Transformation in a Global Context

\begin{tabular}{|c|c|c|}
\hline Country & Flow & Stock \\
\hline Equatorial Guinea & 22.4 & 260.9 \\
\hline Eritrea & 0.9 & 104.6 \\
\hline Ethiopia & 102.5 & 771.8 \\
\hline Gabon & 32.1 & 168.5 \\
\hline Gambia & - & 1.2 \\
\hline Ghana & 122.5 & 834.8 \\
\hline Guinea & 100.1 & 338.6 \\
\hline Guinea-Bissau & - & 27.0 \\
\hline Kenya & 230.5 & 636.0 \\
\hline Lesotho & - & 9.1 \\
\hline Liberia & 30.3 & 196.1 \\
\hline Libya & 0.5 & 108.8 \\
\hline Madagascar & 15.5 & 286.1 \\
\hline Malawi & 8.3 & 253.8 \\
\hline Mali & 108.1 & 316.7 \\
\hline Mauritania & 15.3 & 108.3 \\
\hline Mauritius & 61.1 & 850.0 \\
\hline Morocco & 7.7 & 103.1 \\
\hline Mozambique & 131.9 & 508.1 \\
\hline Namibia & 7.1 & 349.5 \\
\hline Niger & 116.4 & 241.9 \\
\hline Nigeria & 209.1 & $2,146.1$ \\
\hline Rwanda & -6.0 & 73.3 \\
\hline São Tomé and Príncipe & - & 0.4 \\
\hline Senegal & 10.4 & 83.3 \\
\hline Seychelles & 17.7 & 103.5 \\
\hline Sierra Leone & 40.0 & 108.4 \\
\hline South Africa & -89.2 & $4,400.4$ \\
\hline South Sudan & 11.5 & 26.5 \\
\hline Sudan & 140.9 & $1,507.0$ \\
\hline Tanzania & 150.6 & 716.5 \\
\hline Togo & 23.6 & 123.1 \\
\hline Tunisia & 7.1 & 13.9 \\
\hline Uganda & 60.6 & 383.8 \\
\hline Zambia & 292.9 & $2,164.3$ \\
\hline Zimbabwe & 517.5 & $1,520.8$ \\
\hline Africa total & $3,370.6$ & $26,185.8$ \\
\hline
\end{tabular}

- = not available.

Source: (MOFCOM 2014). 
Lumpy across time and countries, official Chinese FDI data (Table 16.1) for 2013 reveal the consistent recent tendency for fuel and metal suppliers to receive the lion's share of China's Africa-bound FDI. Across the past decade, the largest annual recipients of Chinese FDI in Africa were Nigeria in 2003; Sudan in 2004, 2005 and 2011; Algeria in 2006, 2009 and 2012; South Africa in 2007, 2008 and 2010; and Zimbabwe in 2013. Countries in recent years that have received more than 5 per cent of total Chinese FDI into Africa include Kenya, Angola and Sudan - the last two being China's most important African oil suppliers.

Despite this prominence of commodities in China-Africa ties, neither of the largest two single investments by China in Africa arose within the commodities sector; they were in finance and in infrastructure. In 2008 the Industrial and Commercial Bank of China (ICBC) acquired 20 per cent of South Africa's Standard Bank for US $\$ 5.6$ billion (Standard Bank 2011), while in November 2014, Africa became home to China's largest-ever outbound FDI transaction. That deal is between Nigeria, Africa's largest economy, and state-owned China Railway Construction Corporation Limited. When complete, the 22-stop, 1,400-kilometre railway line will connect Nigeria's most populous city, Lagos, in the west, along the coast to Calabar in the east, creating 200,000 construction jobs in Nigeria and generating US\$4 billion in Chinese equipment exports. ${ }^{3}$

Non-commodity investments in general - including in wholesale trade, retail catering and textiles - often fall outside China's official investment statistics, the reliability of which generally remain of concern (Rosen and Hanemann 2009: 3). The scale of mainland Chinese FDI into Africa that passes via Hong Kong and other offshore centres is similarly not known, but is significant.

Structural factors also help to explain these patterns. China became dependent on foreign sources of energy from the early 1990s and its 'going out' policy explicitly prioritised investment in natural resources in which Chinese import demand was strong. More recently, labour in China has also become relatively scarce and more expensive. Selective African countries, in contrast, offer young, rapidly increasing and, on average, lesser-educated populations, in an environment that is more politically and macroeconomically stable than in earlier decades. Rising Chinese investment interest in Africa is what one would expect from analysis based on relative factor endowments and costs (see Krueger 1977).

The commodity-focused pattern of investment supports resources serving as collateral for high-risk investment financing - a model of Chinese investment known as 'Angola terms'. However, the presence of resources seems to affect only the level of investment, not the decision to invest (Cheung et al. 2012). A link between commodity wealth and corruption in Africa (see Leite and

3 See: www.out-law.com/en/articles/2014/november/china-signs-contract-for-coastal-rail-project-in-nigeria/. 
Weidmann 1999) could also help explain why, from 2003 to 2006, China's foreign investment in 26 African countries was biased towards natural resources and poor governance (Kolstad and Wiig 2011).

The associated increase in Chinese investor interest in such diverse countries as Vietnam, Bangladesh, Ethiopia and Tanzania reflects a new phase in an old process in which China itself served as a low-cost investment destination. This process of transfer of industrial processes from higher to lower-wage countries is described by the multi-tiered, hierarchical 'flying geese' model (Akamatsu 1961, 1962). The model traces the spread of industrialisation from more to lesser developed economies - the initial 'goose' (the more advanced economy) leads the second-tier 'geese' (lesser advanced economies), which are followed by third-tier geese (least-developed economies) through a process of gradual production transfer.

While the model describes the iterative industrialisation process that was followed by Japan, South Korea and Taiwan in their investments in China and elsewhere in Asia, Lin and Wang (2014) compare the different scale of China's flying geese potential with that of Japan and Korea at a similar stage. According to their numbers, Japan in 1960 had 9.7 million workers in manufacturing and in 1980 Korea had 2.3 million. China, by comparison, is presently home to something closer to 100 million factory jobs. A comparable transfer of factory jobs abroad could thus logically be an immense driver of employment and industrialisation in today's poor countries.

There are an increasing number of examples from China in Africa of this potentially greatest-ever gander of flying geese. Textile giant China JD Group's textile factory now produces textiles once produced in China for export to the United States - from Tanzania. In Ethiopia, China's Huajian Group plans to invest some US\$2 billion in the coming decade, expanding a nascent shoemanufacturing cluster that exports within Africa, and also to Europe and North America. The plan makes use not only of Ethiopia's comparatively low wages, but also of intra-African trade preferences and its LDC trade preferences.

Investments in the automotive sector similarly seek to utilise low wages and intra-African trade preferences. A US $\$ 50$ million Foton Motors vehicle assembly plant in Nairobi, Kenya, opened in 2012. The plant has capacity to manufacture up to 10,000 pick-up trucks and light commercial vehicles annually, and targets its output to the emerging East African market. Similarly, state-led Beijing Automotive Industry Holding Company, one of China's largest automotive manufacturers, and South Africa's Industrial Development Corporation, since 2013, together run Beijing Automotive Works (BAW) South Africa. The joint US $\$ 17.8$ million minibus assembly line brings South Africa closer to its goal of full domestic manufacture of minibus taxis (Global Post 2015). 
Table 16.2 Geographic distribution of China's outbound FDI flows, 2013

\begin{tabular}{|l|r|r|r|}
\hline Continent & Amount & Share (\%) & Annual growth \\
\hline Asia* & 75.60 & 70.1 & 16.7 \\
\hline Europe & 5.95 & 5.5 & -15.4 \\
\hline Latin America & 14.36 & 13.3 & 132.7 \\
\hline North America & 4.90 & 4.5 & 0.4 \\
\hline Africa & 3.37 & 3.2 & 33.9 \\
\hline Oceania & 3.66 & 3.4 & 51.6 \\
\hline Total & 107.84 & 100.0 & 22.8 \\
\hline
\end{tabular}

* Includes investment channelled through Hong Kong to third destinations.

Source: NBS (2014: 85).

Despite an ever-increasing number of such investment projects, China's outbound FDI to African destinations is small relative to China's total outbound FDI and to total inbound FDI into Africa. In 2013 Africa attracted just 3.2 per cent of total Chinese outbound FDI (Table 16.2). And yet, few topics in applied development economics attract more media scrutiny, and less attention from empirical economists.

Future directions in China's investments in Africa can be deduced from political speeches and the combination of excess supply capacity in China and large development needs, suggesting that a good proportion of China's US\$1 trillion investment target for Africa will focus on infrastructure.

Visiting Africa in May 2014, Premier Li spoke directly of connecting African capitals using China's high-speed rail technology. In Africa in January 2015, Chinese Foreign Minister Wang Yi reiterated China's commitment to helping Africa build the 'three major networks': railway, road and regional aviation. In Ethiopia at the 2015 heads-of-state meeting of the 54-member African Union (AU), China signed the 'African Union-China deal'. This is billed as the most substantive project the AU has ever signed with a partner, and promises to connect the continent by road, rail and air transportation.

In aviation, privately owned Hainan Airlines agreed to inject US $\$ 50$ million into Kenya's Astral Aviation in 2014. The memorandum agrees to develop Kenya's Nairobi Jomo Kenyatta airport into a regional East African aviation hub using funds from China's China-Africa Development Fund. Senegal, Sudan, Togo and Djibouti are among countries that have ongoing airport construction projects that include a Chinese partner (Radliki 2015).

Under China's flagship 'One Belt and One Road' initiative, several deep-water coastal ports in Africa are also in progress: Bizerte in Tunisia; Dakar, Senegal; Dar es Salaam, Tanzania; Djibouti, Djibouti; Libreville, Gabon; Maputo, Mozambique; 
and Tema, Ghana. These are intended to facilitate Africa's own economic development, as well as to serve as locations for transcontinental trade between Chinese and African economies, along the 'maritime Silk Road'.

The focus on infrastructure reflects the importance of easing 'bottle-necks in domestic and intra-regional economic development' (Lin and Wang 2014: 13). China's high level of foreign exchange reserves, coupled with excess capacity and competitive strength in infrastructure and related industries, can convert Africa's development requirements into new sources of foreign income and international brand recognition. It can also help to realise China's geo-economic and geopolitical ambitions via railway and maritime trade routes.

Chinese investors are similarly investing in downstream infrastructure-related industries. In late 2014, Hebei Iron \& Steel, China's largest steelmaker, announced plans to relocate 5 million tonnes of production (roughly 11 per cent of its annual output) to South Africa. In March 2015, state-owned giant steelmaker Sinosteel signed a memorandum of understanding with the Government of Kenya to build a 'steel city' outside Nairobi towards meeting Kenya's rising domestic and regional steel demand (Muhoro 2015).

At the raw commodities level, in 2014 China was also party to a US $\$ 20$ billion agreement with Rio Tinto, Chinese state-owned aluminium giant Chinalco, the Government of Guinea and the International Finance Corporation. The deal will develop Guinea's Simandou iron ore deposits - home to almost 2 billion tonnes of mostly high-grade iron ore. It is the largest combined iron ore and infrastructure project ever attempted in Africa.

Similarly, in April 2015, Shandong Iron and Steel Group reported acquiring the remaining 75 per cent share of Sierra Leone's Tonkolili iron ore mine, and the associated infrastructure company, African Port and Railway Services. Shandong plans to lift production at the mine to 25 million tonnes per year (Cornish 2015; Macrobusiness 2015). The academic literature has considered the potential for Africa's iron ore reserves to supply Chinese demand (Hurst 2013). The potential to supply rising steel demand in Africa is of increasing importance to Africa, China and the global mining industry.

Across Africa, urbanisation and infrastructure development are increasing demand for steel. ${ }^{4}$ In Kenya, government projections suggest that domestic demand for steel will rise, from 1.8 million metric tonnes in 2013 to 2.5 million tonnes by 2020, and then to double by 2030 (Ministry of Industrialisation and Enterprise Development of Kenya 2015). These developments are being assisted by Chinese infrastructure investments, including the Chinese-led East

4 From Nairobi, the railway line will extend to Uganda, Rwanda, Burundi and South Sudan. 
African standard-gauge railway that is under construction, to be completed by early 2018. This project will link five East African countries: Kenya, Uganda, Rwanda, Burundi and South Sudan. The nascent Chinese-founded multilateral Asian Infrastructure Investment Bank has received support from the President of the African Development Bank for institutional cooperation to provide the capital and support for such growth forecasts.

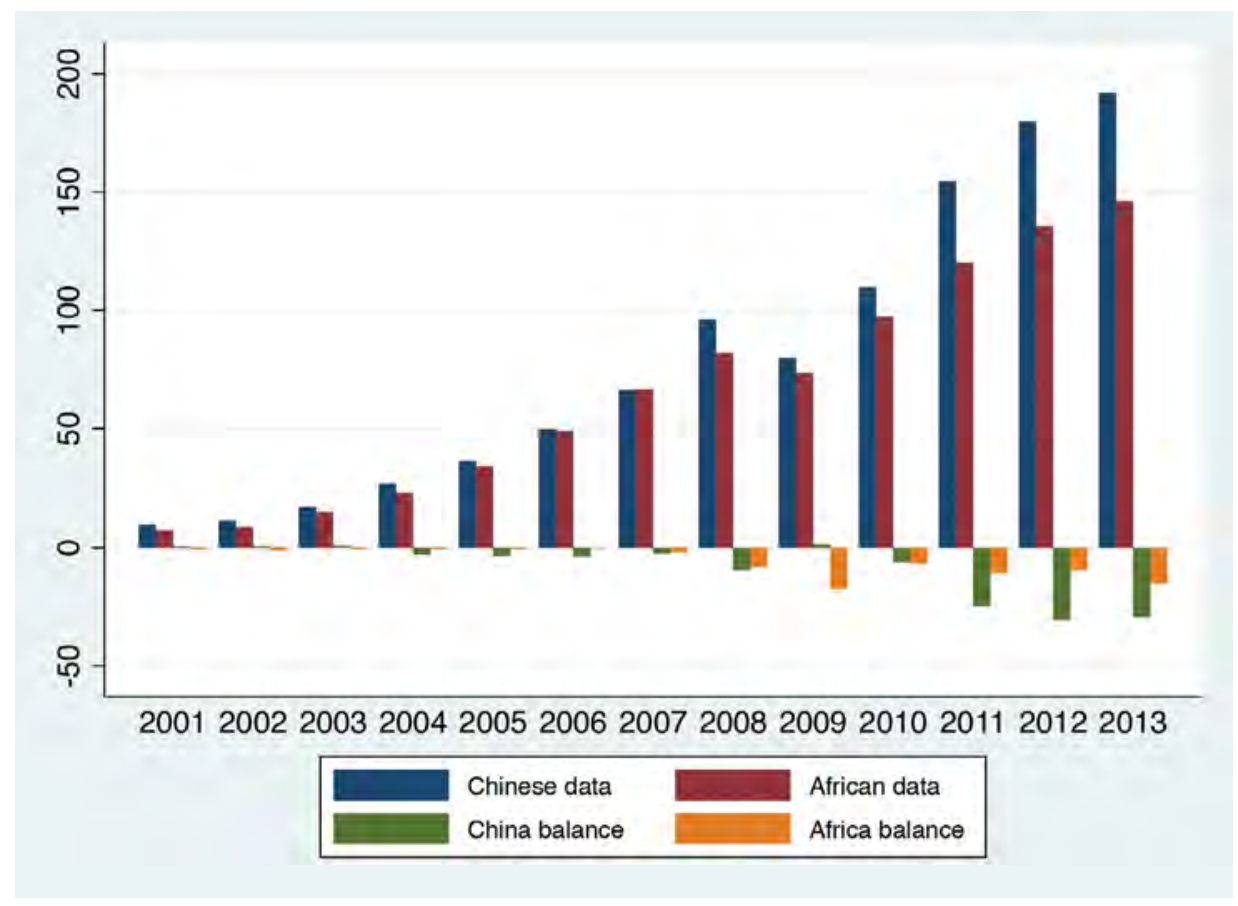

Figure 16.2 China-Africa trade (US\$ billion)

Source: IMF (2015a). Trade balances reflect the author's own calculations.

While Chinese FDI in Africa is expected to rise rapidly, presently China-Africa trade levels dwarf those of aid and FDI combined. According to Chinese data, total Sino-African trade value reached US\$192 billion in 2013 (Figure 16.2). This comprised Chinese imports of US\$111 billion from Africa and exports of US $\$ 81$ billion - a figure more than 10 times higher than the US $\$ 10$ billion value of trade in 2000 (IMF 2015a). Aggregated African data, however, report a lower total trade level for 2013, of US\$146.1 billion.

Sino-African trade is proportionately more important to Africa than to China. Trade with China made up 14 per cent of total African reported trade in 2013. China's trade with Africa, however, made up just 4.6 per cent of total reported Chinese trade that year (IMF 2015a). African data point to a trade deficit with China of US\$15.2 billion in 2013. That year, China reported a deficit in trade with Africa, of US\$29.4 billion (ibid). 
Oil makes Chinese imports larger than exports in trade with Africa (Ademola et al. 2009; Thomson and Horii 2009). Oil imports have risen significantly in recent years. In 1990, China imported no oil from Africa. By 2010, roughly one-quarter of its foreign oil supply was being sourced from the continent (Thompson and Horii 2009: 648).

Table 16.3 Selective 'top-10' Africa-China export indicators, 2013

\begin{tabular}{|l|r|l|r|}
\hline Country & Export volume (US\$b) & Country & Export intensity (\%) \\
\hline Angola & 29.0 & Sierra Leone & 78.1 \\
\hline South Africa & 11.8 & Gambia & $57.0^{*}$ \\
\hline Congo Republic & 5.2 & Mauritania & 55.5 \\
\hline Congo, DR & 2.5 & Congo Republic & 53.5 \\
\hline Zambia & 2.4 & Angola & 45.9 \\
\hline Mauritania & 1.6 & Congo, DR & 42.2 \\
\hline Nigeria & 1.4 & Mali & 30.1 \\
\hline Sierra Leone & 1.3 & Zambia & 25.5 \\
\hline Gabon & 0.8 & Burkina Faso & 24.8 \\
\hline Ghana & 0.7 & Rwanda & 24.3 \\
\hline Zimbabwe & 0.6 & Zimbabwe & 23.6 \\
\hline Egypt & 0.6 & Benin & 21.2 \\
\hline Africa & 65.4 & Africa & 14.3 \\
\hline
\end{tabular}

${ }^{*}$ A significant share of which are re-exports from other West African countries.

Note: Author's own calculations, and where export intensity is weighted by country, not by travel level. Source: IMF (2015a), where export intensity is defined as the ratio of exports to China over a country's total exports.

Data in Table 16.3 make the point that of China's top-10 African exporters, half have oil as the main export-Angola, Republic of the Congo, Ghana, Nigeria and Gabon. The remainder of the top 10 are minerals exporters. Countries in Africa with fewer minerals and fuel exports have much less favourable trade complementarities and thus lower export intensities with China. Countries exporting less than 1 per cent of their total exports to China in 2013 include Kenya, Senegal, Tunisia, Morocco, Djibouti and the island nations of Mauritius, São Tomé and Príncipe, Comoros and Cape Verde (IMF 2015a).

These trade tendencies are congruent with old trade theory. A condition of trade under the Heckscher-Ohlin (1991) model is that trade should arise between two countries that differ with respect to their relative factor endowments - primarily labour, capital and natural resources. The model demonstrates that the gains to trade around specialisation are greatest when the country with abundant capital and scarce labour specialises in the production of goods that utilise capital most intensively, and vice versa. 
Accordingly, China is not alone in having imports from Africa dominated by fuels and minerals. Even where oil and gas-rich North African countries are excluded, imports to the European Union and the United States from subSaharan Africa are still dominated by minerals and fuels (see Gualberti et al. 2014). According to the study by Gualberti et al. (2014), in 2012 fuel represented some 76 per cent of the United States' imports from SSA - more than China's 72 per cent. Africa's imports from China, in contrast, are driven mainly by machinery, chemicals and manufactured goods, though patterns vary somewhat among importers (Drummond and Liu 2013).

Strong export specialisation in commodities can have negative externalities, including through 'Dutch disease'. Dutch disease arises when a surge in the value of commodity exports pushes up the real exchange rate, reducing the competitiveness of other, including industrial, sectors (Corden and Neary 1982).

\section{China-Africa economics research}

Alongside hope for greater African international economic integration, there is cynicism about China's growing investment and trade ties with Africa. The worry is that what is perceived as the colonial outcome will be repeatedlarge-scale extraction of resources for little indigenous return.

While it is early days yet for assessing the long-run nature of the return of the 'fleeting old normal', it is not too early to assess some impacts. The ChinaAfrica literature identifies both positive and negative effects of expanding Sino-African economic ties. These depend to a large extent on mineral resource endowments (Jenkins and Edwards 2005; Kaplinsky 2005; Zafar 2007).

China led strong growth in demand for energy and metals over the first decade of this century, causing a rapid rise in related prices from 2003 to 2011, with a brief interlude for the global financial crisis (GFC) (Garnaut, forthcoming). Declining prices since 2011, however, reflect China's progress towards its goal of using less energy, especially coal, per unit of GDP.

China's demand growth for energy and metals decelerated just as global supply growth was building strong momentum. Oil and copper are among China's important imports from Africa, the latter especially in trade with Zambia. The prices of both oil and copper peaked in 2011, before declining through to early 2015 (Chapter 2 in this volume).

Prior to the passing of the peak of the China-led commodities boom, research had identified some of the impacts of China's trade and investment ties on African economies. Indirect trade impacts, including the diversion of investment and labour to the extractive sector at the expense of manufacturing (Dutch disease), 
is found to have adversely affected the horticulture and textiles sectors of Zambia (Bova 2008), and Africa's resource exporters more generally (Kaplinsky and Morris 2008). Commodity trade with China has also displaced light manufacturing in selected African countries (Giovannetti and San Filippo 2009; Kaplinsky and Morris 2008; Khan and Baye 2008). At least during the years of the commodities boom, African countries that were strongly specialised in exports of commodities tended to experience stronger and more broadly based growth than countries with more diverse exports (Baliamoune-Lutz 2011). Change under way in China's own economy, however, means that the China-led resources boom is now fading, and may narrow that gap.

Imports from China have contributed to African development (BaliamouneLutz 2011; Maswana 2010). Low-cost Chinese manufactures suit average income levels and thus consumption budgets in many African economies. Intensity of import trade with China varies less across countries than intensity of exports to China (Johnston et al. 2014: 6).

The 50 per cent fall in the oil price, from June 2014 to March 2015, is explored by Hou et al. (2015). For the continent as a whole, the report cites research suggesting that a 30 per cent drop in oil prices (smaller than the recent decline) is projected to directly reduce the value of oil exports in SSA by US\$63 billion and reduce imports by an estimated US\$15 billion.

Table 16.4 Oil importer and exporter groupings, top 10, Africa, 2013

\begin{tabular}{|c|c|}
\hline \multicolumn{2}{|l|}{ Oil exporters } \\
\hline Net oil exporters & $\begin{array}{l}\text { Nigeria, Angola, Algeria, Libya, Equatorial Guinea, Congo } \\
\text { Republic, Gabon, Sudan, Chad, Ghana }\end{array}$ \\
\hline Oil export dependency & $\begin{array}{l}\text { Chad, Angola, Libya, Gabon, Nigeria, Congo Republic, Sudan, } \\
\text { Equatorial Guinea, Algeria, Cameroon }\end{array}$ \\
\hline Oil exports as share of GDP & $\begin{array}{l}\text { Equatorial Guinea, Angola, Congo Republic, Gabon, Libya, } \\
\text { Chad, Nigeria, Algeria, Côte d'Ivoire, Sudan }\end{array}$ \\
\hline \multicolumn{2}{|l|}{ Oil importers } \\
\hline African net oil importers & $\begin{array}{l}\text { South Africa, Morocco, Tanzania, Kenya, Egypt, Ethiopia, } \\
\text { Zimbabwe, Mozambique, Uganda, Senegal }\end{array}$ \\
\hline Oil import dependency & $\begin{array}{l}\text { Tanzania, Guinea, Mali, Côte d'Ivoire, Senegal, Gambia, } \\
\text { Burkina Faso, Kenya, Mauritania, São Tomé and Príncipe }\end{array}$ \\
\hline Oil imports as a share of GDP & $\begin{array}{l}\text { Liberia, Mauritania, Tanzania, Seychelles, São Tomé and } \\
\text { Príncipe, Zimbabwe, Senegal, Guinea, Mali and Mozambique }\end{array}$ \\
\hline
\end{tabular}

a Listed in order of magnitude.

Source: Hou et al. (2015).

The effects at the country level depend primarily on whether a country is an oil exporter or importer. Table 16.4 lists countries in order of the scale of oil exports and imports, and shows the relative importance of oil in trade value, fiscal 
revenues and production (GDP). Countries listed in the top half of the table-oil exporters - are suffering a loss of direct revenues from oil sales. The result is a painful revision of budget plans, with Ghana, Gabon, Angola and the Republic of the Congo all reported to be cutting back on national expenditure plans this year (Games 2015). For those in the bottom half of Table 16.5, however, the drop in oil price provides an improvement in the terms of trade.

Hou et al.'s (2015) overview of the impacts of the oil price crash on Africa also shows how declining resources exports lead to real exchange rate depreciation in many countries. This expands opportunities for trade and investment in other sectors, with favourable development effects. There is a chance of a long-run positive story for Africa, and China-Africa - the chance of a 'boom to cusp'. The opportunity is for movement from a commodities boom to the cusp of a sustainable industrial transition and integration with the world economy.

Table 16.5 Selective net oil importer economic ties with China

\begin{tabular}{|l|r|r|r|l|}
\hline Country & Export dependence & FDI stock & BIT in force Infrastructure $^{\mathbf{a}}$ \\
\hline Tanzania & 13.2 & 717 & 2014 & Port \\
\hline Kenya & 0.9 & 636 & 2001 & Rail \\
\hline Ethiopia & 12.8 & 772 & 1998 & Rail $^{\mathrm{b}}$ \\
\hline
\end{tabular}

a Not a complete list of China-invested infrastructure projects.

${ }^{\mathrm{b}}$ Associated with a port extension in Djibouti, at a port that is relied on by landlocked Ethiopia.

Sources: IMF (2015a); MOFCOM (2014); Johnston and Yuan (2014); UNCTAD (2015); various news sources.

Table 16.5 highlights selected stylised facts about China's economic ties with three net oil importers in Africa. These countries are especially important to the idea of 'boom to cusp' because they are three economies that China has nominated to become hubs for its outbound investment in Africa. All are in East Africa and currently have low export intensities with China as against more resource-rich countries. All have signed a bilateral investment treaty with China and are direct or indirect beneficiaries of China's infrastructure investments in Africa.

Advantageously in a context of long-run economic development, two of the three economies are also classed as coastal and resource-poor (CRP) economies (Collier and O'Connell 2007). The significance of CRP status relates to recent findings on the relationship between sustainable economic transformation between countries and over time. Specifically, in the second half of the twentieth century, it was when CRP countries began to sustainably industrialise that growth elsewhere in a region/continent - in resource-rich economies and in landlocked resource-poor economies - was likely to produce a broader, more sustainable transformation (World Bank Staff 2008) than is more typical of growth around resources trade. 
Over the years 1995-2009, Johnston et al. (2014) identified China to have relatively weak trade and economic policy ties with economies in sub-Saharan Africa with supply and exploitation of weak national resource endowments, against an empirical benchmark derived from gravity modelling. Given the scale of China's African ties, especially with resource exporters, the authors concluded that China's weaker ties with non-resource exporting coastal economies could undermine hope for sustainable long-run regional economic growth and development.

The terms of trade have since shifted in favour of coastal and resource-poor economies. The commodities crash presents a painful shift for established commodities exporters, but is good news for net resource importers in Africa.

This is potentially good news for finding new sources for sustainable long-term economic growth in Africa. The United Nations projects that on current fertility rates by 2050 Africa's population will be double what it is at present. Under the UN assumptions, Nigeria's population will reach some 400 million and Kenya will have a population of almost 100 million. This makes now a good time to construct the tangible and intangible economic infrastructure that will support that future population.

\section{The largest-ever gander or brace of Peking's ducks in Africa?}

The depth and breadth of China-Africa ties suggest that slower growth in China will slow growth in Africa. This chapter has, however, traced an underlying good news story in the new normal of China and Africa. That story relates to longerterm potential of the shift towards more diverse African export specialisation combined with excess capacity in China's steel and infrastructure industries. Lessons from other regions' experiences with industrial transformation mean that the pattern of China-Africa ties as a result of the 'new normal' could contribute positively to African development.

China is a continental-sized economy facing tight resource constraints. Home of the world's largest and an ageing population, its slowing economy offers cheap capital and internationally competitive industrial, including infrastructure, capacity. Africa, in contrast, offers a fast-growing and young population, and relatively high natural resource and arable land levels per capita. On the whole, it is in need of massive infrastructure investment, affordable financial capital and investors with an appetite for risk. 
Economic historian Angus Maddison identified that it took 1,400 years to double per capita income before the eighteenth century. As the Industrial Revolution spread, however, it took only 70 years to double per capita income from the late eighteenth century to the mid-nineteenth century. In the second half of the twentieth century, it took only 35 years for developed countries to double per capita income (Maddison 2001; World Bank 2008, cited in Lin and Wang 2014). This process of economic transformation has since been even faster in 13 rapidly growing emerging economies. Many of these-including Korea, Taiwan and other East Asian newly industrialised economies, and later China-have followed a pattern of development that can be described by the flying-geese model elaborated on earlier in this chapter.

Economic logic indicates that as African countries continue to accumulate human, physical and financial capital, their export structures will transform and upgrade.

Africa's process will be its own, but this does not preclude lessons from East Asia's experience being valuable reference points for the China-Africa story. The success of the China-Africa partnership, that is, might help to transform not only China's international economic prospects, but also those of Africa.

\section{References}

Ademola, O.T., Bankole, A.S. and Adewuyi, A.O. (2009), China-Africa trade relations: Insights from AERC scoping studies, European Journal of Development Research, 21(4): 485-505.

Akamatsu, K. (1961), A theory of unbalanced growth in the world economy, Weltwirtschaftliches Archiv, 86: 196-217.

Akamatsu, K. (1962), A historical pattern of economic growth in developing countries, The Developing Economies, (1): 3-25.

Alden, C. (2007), China in Africa, London: Zed Books.

Arbache, J. and Page, J. (2007), Patterns of long term growth in sub-Saharan region, Washington, DC: The World Bank.

Baliamoune-Lutz, M. (2011), Growth by destination (where you export matters): Trade with China and growth in African countries, African Development Review, 23: 202-18.

Bova, E. (2008), Exchange rate management for commodity booms: Examining Zambia's copper exports, Development Viewpoint 19, London: Centre for Development Policy and Research, School of African and Oriental Studies. 
Brandt, P. (2013), Chinese aid to Africa: A detective story, Lowy Interpreter, Sydney: Lowy Institute. Available from: www.lowyinterpreter.org/ post/2013/05/02/Chinese-aid-to-Africa-A-detective-story.aspx. Retrieved 10 January 2014.

Brautigam, D. (2009), The dragon's gift: The real story of China in Africa, Oxford: Oxford University Press.

Brautigam, D. (2011), Chinese development aid in Africa: What, where, why, and how much?, in Golley, J. (ed.), Rising China: Global challenges and opportunities, Canberra: ANU E Press.

Brautigam, D. and Tang, X. (2011), African Shenzhen: China's special economic zones in Africa, Journal of Modern African Studies, 49(1): 27-54.

Broadman, H. (2007), Africa's silk road: China and India's new economic frontier, Washington, DC: The World Bank.

Carmody, P. (2009), An Asian-driven economic recovery in Africa? The Zambian case, World Development, 27: 1197-207.

Cheung, Y.-W., Haan, J., Qian, X. and Yu, S. (2012), China's outward direct investment in Africa, Review of International Economics, 20(2): 201-20.

Collier, P. and O'Connell, S. (2007), Opportunities and choices, in Ndulu, B., O'Connell, S.A., Bates, R.H., Collier, P. and Soludo, C.C. (eds), Political economy of economic growth in Africa, 1960-2000, Cambridge: Cambridge University Press.

Corden, W.M. and Neary, J.P. (1982), Booming sector and de-industrialisation in a small open economy, The Economic Journal: 825-48.

Cornish, L. (2015), Shandong Iron and Steel acquires Tonkolili mine in Sierra Leone, Mining Review, 21 April. Available from: www.miningreview.com/ shandong-iron-and-steel-acquires-tonkolili-mine-in-sierra-leone/. Retrieved 30 April 2015.

de Grauwe, P., Houssa, R. and Piccillo, G. (2012), African trade dynamics: Is China a different trading partner?, Journal of Chinese Economic and Business Studies, 10(1): 15-45.

Dreher, A., Fuchs, A., Hodler, R., Parks, B., Raschky, P.A. and Tierney, M.J. (2014), Aid on demand: African leaders and the geography of China's foreign assistance, AidData Working Paper No. 3, 18 November. Available from: dx.doi.org/10.2139/ssrn.2531966. 
Dreyer, E.L. (2007), Zheng He: China and the oceans in the early Ming Dynasty, 1405-1433, New York: Pearson Longman.

Drummond, M.P. and Liu, M.E.X. (2013), Africa's rising exposure to China: How large are spillovers through trade?, Working Paper No. 13-250, Washington, DC: International Monetary Fund.

Financial Times (2013), Africa must get real about Chinese ties, Financial Times, 11 March. Available from: www.ft.com/intl/cms/s/0/562692b0-898c-11e2ad3f-00144feabdc0.html\#axzz2Ww2Horkg. Retrieved 28 January 2015.

Fletcher, R. and Ahmed, K. (2012), Davos 2012: China and Africa to be centre of world trade, The Telegraph, 26 January. Available from: www.telegraph. co.uk/finance/financetopics/davos/9042156/Davos-2012-China-and-Africato-be-centre-of-world-trade.html. Retrieved 5 March 2012.

Games, D. (2015), Africa: Bust or boom?, AllAfrica, 25 January. Available from: allafrica.com/stories/201504031455.html. Retrieved 4 May 2015.

Garnaut, R. (2006), The China resources boom, Presented to Australian Agriculture and Resource Economics Conference, February, Sydney.

Garnaut, R. (2012), The contemporary China resources boom, Australian Journal of Agricultural and Resource Economics, 56(2): 222-43.

Garnaut, R. (forthcoming), Indonesia's resources boom in international perspective: Policy dilemmas and options for continued strong growth (the Ninth Sadli Lecture), Bulletin of Indonesian Economic Studies.

Giovannetti, G. and Sanfilippo, M. (2009), Do Chinese exports crowd-out African goods? An econometric analysis by country and sector, European Journal of Development Research, Special Issue 24: 506-30.

Global Post (2015), Feature: The story, ambition of Chinese auto manufacturer in Africa, Global Post, 8 April. Available from: www.globalpost.com/ article/6509105/2015/04/08/feature-story-ambition-chinese-automanufacturer-africa. Retrieved 17 April 2015.

Gualberti, G., Bazilian, M. and Moss, T. (2014), Energy investments in Africa by the US, Europe and China, Cleveland: International Association for Energy Economics.

Heckscher, E.F. and Ohlin, B. (1991), Heckscher-Ohlin trade theory, H. Flam and M. June Flanders trans., eds and intro., Cambridge, Mass.: MIT Press. 
Hook, L. (2012), Zuma warns on Africa's ties to China, Financial Times, 19 July. Available from: www.ft.com/intl/cms/s/0/33686fc4-d171-1lel-bbbc00144feabdc0. Retrieved 1 July 2014.

Hou, Z., Keane, J., Kennan, J. and te Velde, D.W. (2015), The oil price shock of 2014, ODI Working Paper 415, London: Overseas Development Institute. Available from: www.odi.org/sites/odi.org.uk/files/odi-assets/publicationsopinion-files/9589.pdf. Retrieved 3 April 2015.

Hurst, L. (2013), West and Central African iron ore development and its impact on world prices, Australian Journal of Agricultural and Resource Economics, 57(4): 521-38.

International Monetary Fund (IMF) (2015a), Direction of trade statistics, April, Washington, DC: IMF.

International Monetary Fund (IMF) (2015b), Transcript of the African finance ministers press briefing, 18 April, Washington, DC: IMF. Available from: www.imf.org/external/np/tr/2015/tr041815a.htm. Retrieved 8 May 2015.

Jenkins, R. and Edwards, C. (2005), The effect of China and India's growth and trade liberalization on poverty in Africa, DCP 70, London: UK Department for International Development.

Johnston, L.A., Morgan, S.L. and Wang, Y. (2014), The gravity of China's African export promise, The World Economy. doi: 10.1111/twec.12229.

Johnston, L.A. and Yuan, C. (2014), China's Africa trade and investment policies: Review of a 'noodle bowl', African East-Asian Affairs, (4): 6-41.

Kaplinsky, R. (2005), Globalization, poverty and inequality, Cambridge: Polity Press.

Kaplinsky, R. and Morris, M. (2008), Do the Asian drivers undermine exportoriented industrialization in SSA?, World Development, 36(2): 254-73.

Khan, S.A. and Baye, F.M. (2008), China-Africa economic relations: The case of Cameroon, Mimeo., Nairobi: African Economic Research Consortium.

Kolstad, I. and Wiig, A. (2011), Better the devil you know? Chinese foreign direct investment in Africa, Journal of African Business, 12: 31-50.

Krueger, A.O. (1977), Growth, distortions, and patterns of trade among many countries, No. 40, Princeton, NJ: International Finance Section, Department of Economics, Princeton University. 
Leite, C.A. and Weidmann, J. (1999), Does mother nature corrupt? Natural resources, corruption, and economic growth, June, IMF Working Paper No. 99/85, Washington, DC: International Monetary Fund. Available from: ssrn.com/abstract=259928 or http://dx.doi.org/10.2139/ssrn.259928.

Levathes, L. (2014), When China ruled the seas: The treasure fleet of the dragon throne, 1405-1433, New York: Open Road Media.

Lin, J. and Wang, Y. (2014), China-Africa cooperation in structural transformation: Ideas, opportunities, and finances, WIDER Working Paper 2014/046, Helsinki: United Nations University World Institute for Development Economics Research. Available from: www.nsd.edu.cn/cn/userfiles/ Other/2014-03/2014030410441338653249.pdf. Retrieved 20 February 2015.

Macrobusiness (2015), Iron ore shudders as China absorbs Africa, Macrobusiness, 21 April. Available from: www.macrobusiness.com.au/2015/04/iron-oreshudders-china-absorbs-africa/.

Maddison, A. (2001), The world economy: A millennial perspective, Paris: OECD Development Centre.

Mao, X. (2011), The path of China's aid to Africa [in Chinese], Economy, 10.

Maswana, J. (2010), Will China's recovery affect Africa's prospects for economic growth?, JICA Working Papers 19, Tokyo: JICA Research Institute.

Muhoro, M. (2015), China trader Sinosteel clinches Kenya 'steel city' deal, Kenya Construction Business Review, 31 March. Available from: www. constructionkenya.com/3243/sinosteel-clinches-kenya-steel-city-deal/. Retrieved 7 April 2015.

Ministry of Industrialisation and Enterprise Development of Kenya (2015), Kenya signs MOU with Sinosteel - Chinese leading steel development company, Nairobi: Government of Kenya. Available from: www.industrialization. go.ke/index.php/media-center/news-updates/176-press-release-kenyasigns-mou-with-sinosteel-chinese-leading-steel-development-company. Retrieved 10 March 2015.

National Bureau of Statistics (NBS) (2013), 2012 Statistical bulletin of China's outbound foreign direct investment, Beijing: China Statistics Press.

National Bureau of Statistics (NBS) (2014), 2013 Statistical bulletin of China's outbound foreign direct investment, Beijing: China Statistics Press.

Ochelle, F.O. (2015), How slowdown in China may hurt Africa, Ventures Africa. Available from: www.ventures-africa.com/archives/57460. 
Out-Law (2014), China signs contract for coastal rail project in Nigeria, OutLaw, 24 November. Available from: www.out-law.com/en/articles/2014/ november/china-signs-contract-for-coastal-rail-project-in-nigeria/.

Pang, X. (2010), Chinese vice president calls for stronger FOCAC, People's Daily, 19 November. Available from: english.people.com. cn/90001/90776/90883/7204133.html. Retrieved 10 September 2011.

Pannell, C. (2013), China's economic and political penetration in Africa, Eurasian Geography and Economics, 49: 706-13.

Ministry of Commerce (MOFCOM) (2011), China's foreign aid whitepaper, China Daily, 22 April. Available from: english.mofcom.gov.cn/article/newsrelease/ press/201309/20130900285772.shtml. Retrieved 4 May 2013.

Ministry of Commerce(MOFCOM) (2013), White paper on China-Africa economic and trade cooperation, China Daily, 22 April. Available from www.chinadaily. com.cn/cndy/2011-04/22/content_12373944.htm. Retrieved 5 May 2011.

Ministry of Commerce (MOFCOM) (2014), 2013 Statistical Bulletin of China's Outward Foreign Direct Investment. China Statistics Press.

Ministry of Foreign Affairs, Premier Zhou Enlai's Three Tours of Asian and African countries. Available from: http://www.fmprc.gov.cn/mfa_eng/ ziliao_665539/3602_665543/3604_665547/t18001.shtml. Retrieved 20 May 2015.

Publish What You Fund (2014), 2014 Aid transparency index, Publish What You Fund. Available from: www.publishwhatyoufund.org/index/2014-ati/. Retrieved 24 October 2014.

Radelet, S. (2010), Emerging Africa: How 17 countries are leading the way, Washington, DC: Center for Global Development.

Radliki, M. (2015), From Sudan to Senegal, Africa's head-turning new airports ... with a helping hand from Chinese friends, Mail and Guardian, 6 May. Available from: mgafrica.com/article/2015-03-03-africas-new-airports. Retrieved 11 April 2015.

Rosen, D. and Hanemann, T. (2009), China's changing outbound foreign direct investment profile: Drivers and policy implications, Policy Brief 09-14, Washington, DC:PetersonInstitutefor InternationalEconomics. Availablefrom: www.iie.com/publications/pb/pb09-14.pdf. Retrieved 3 February 2014.

Shen, X. (2015), Private Chinese investment in Africa: Myths and realities, Development Policy Review, 33(1): 83-106. 
Standard Bank (2011), China and the US in Africa: Measuring Washington's response to Beijing's commercial advance, Economic Strategy, BRIC and Africa, Johannesburg: Standard Bank.

The Economist (2011), Africa's impressive growth, The Economist, 1 June. Available from: www.economist.com/blogs/dailychart/2011/01/daily_chart. Retrieved 10 February 2015.

Thomson, E. and Horii, N. (2009), China's energy security: Challenges and priorities, Eurasian Geography and Economics, 50: 643-64.

Tsagas, I. (2013), Chinese PV manufacturers setting up shop in Kenya, PV Magazine, 21 June. Available from: www.pv-magazine.com/ news/details/beitrag/chinese-pv-manufacturers-setting-up-shop-inkenya_100011806/\#ixzz3VxK7hzwY. Retrieved 1 March 2015.

United Nations Conference on Trade and Development (UNCTAD) (2015), International investment agreements navigator: China, bilateral investment agreements, Geneva: UNCTAD. Available from: investmentpolicyhub.unctad. org/IIA/CountryBits/42. Retrieved February 2015.

Wang, J. (2007), What drives China's growing role in Africa?, IMF Working Paper 07/211, Washington, DC: International Monetary Fund.

World Bank (2015), China overview, Washington, DC: The World Bank. Available from: www.worldbank.org/en/country/china/overview.

World Bank Staff (2008), The growth report: Strategies for sustained growth and inclusive development, Washington, DC: World Bank Publications.

Xinhuanet (2013), China's investment in Africa increases 20.5\% annually, Xinhuanet, 29 August. Available from: news.xinhuanet.com/english/ china/2013-08/29/c_132673248.htm. Retrieved 11 September 2012.

Zafar, A. (2007), The growing relationship between China and SSA: Macroeconomic trade, investment and aid links, World Bank Research Observer, 22: 103-30.

Zhou, T. (2014), China's second white paper on foreign aid signals key shift in aid delivery strategy, San Francisco: The Asia Foundation. Available from: asiafoundation.org/in-asia/2014/07/23/chinas-second-white-paper-onforeign-aid-signals-key-shift-in-aid-delivery-strategy/. 
This text is taken from China's Domestic Transformation in a Global Context, edited by Ligang Song, Ross Garnaut, Cai Fang \& Lauren Johnston, published 2015 by ANU Press, The Australian National University, Canberra, Australia. 